\title{
Chemical composition and antioxidant capacity of black pepper pericarp
}

\author{
Joon-Goo Lee ${ }^{1}$, Young Chae ${ }^{2}$, Youngjae Shin ${ }^{3}$ and Young-Jun Kim ${ }^{4 *}$
}

\begin{abstract}
Piper nigrum L. is a widely used spice because of its flavour and health effects. It is prepared as black and white pepper, according to the harvest time and inclusion of the outer skin. Pepper pericarp is usually considered waste when making white pepper. In this study, bioactive and flavour compounds and minerals in the pericarp of black pepper were determined to identify its applications. The pericarp contained total phenol, total flavonoid and piperine contents of $1421.95 \pm 22.35 \mathrm{mg} \mathrm{GAE} / 100 \mathrm{~g}, 983.82 \pm 8.19 \mathrm{mg}$ CE/100 $\mathrm{g}$ and $2352.19 \pm 68.88 \mathrm{mg} / 100 \mathrm{~g}$, respectively. There were higher levels of total phenols and total flavonoids in the pericarp compared with black pepper and white pepper. Piperine content was lower in the pericarp than in black pepper. The principal monoterpene compounds in the pericarp were a-pinene (9.2\%), 2- $\beta$-pinene (14.3\%), $\delta$-3-carene (21.5\%) and DL-limonene (18.8\%), and the primary sesquiterpenes were a-copaene (5.1\%) and caryophyllene (17.2\%). The higher percentages of flavour compounds found in the pericarp would impart a more potent odour, and the pericarp exhibited higher minor and tiny differences based on electronic nose analysis. It had more minerals than black pepper and peeled black pepper.
\end{abstract}

Keywords: Black pepper, Pericarp, Antioxidant, Flavour compound, Mineral, Piperine

\section{Introduction}

Piper nigrum L. is an early and widely used spice in human history and is highly valued for its characteristic pungency. It is prepared as black and white pepper, according to the harvest time and processing method $[1,2]$. Black pepper is the dried immature but fully developed fruit of pepper plants, whereas white pepper consists of the mature fruit devoid of the outer skin (pericarp) [3, 4]. Black pepper has been used as a spice and in herbal medicines. It also has applications as a preservative and biocontrol agent [5]. The essential oil or extract of black pepper displays antioxidant, anti-fungal, anti-amoebic, anti-asthmatic, anti-diabetic and immunomodulatory activities $[3,6,7]$. White pepper has many different applications too, such as a preservative, insecticide, anti-bacterial, anti-fungal and anti-protozoal herb $[5,8,9]$. Especially, black and white peppers contain a

\footnotetext{
*Correspondence: kimyj@seoultech.ac.kr; Kimjy@seoultech.ac.kr

${ }^{4}$ Department of Food Science and Technology, Seoul National University

of Science \& Technology, Nowon, Seoul, 01811, South Korea

Full list of author information is available at the end of the article
}

bioactive compound named piperine, also found in other members of the pepper family (Piperaceae), including long pepper (Piper longum). Piperine is the most abundant and active alkaloid in pepper. It is used as a therapeutic agent because of its many health benefits associated with its antioxidant, anti-inflammatory and drug activity-enhancing activities, respiratory effects and inhibitory action on lung metastasis [10]. Spatial memory and neurodegeneration of Alzheimer can be improved by piperine in animal models [11].

Black pepper is composed of carbohydrate of $37.4 \%$, proteins of $25.5 \%$, fibres of $23.6 \%$, moisture of $4.7 \%$ and fat of $5.3 \%$, as well as minerals, including $0.66 \%$ potassium $(\mathrm{K}), 0.20 \%$ calcium $(\mathrm{Ca}), 0.16 \%$ phosphorus and $0.16 \%$ magnesium $(\mathrm{Mg})[12,13]$. The main volatile flavour compounds in black pepper are terpenes, and black pepper oils contain nitrogen-containing compounds [4, 14]. Key odorants of black pepper are $\alpha$ - and $\beta$-pinene, myrcene, $\alpha$-phellandrene, limonene, linalool, methyl propanal, 2- and 3-methylbutanal, butyric acid and 3-methylbutyric acid. Compounds 2,3-diethyl-5-methylpyrazine and 2-isopropyl-3-methoxypyrazine are responsible for 
the musty and mouldy off-flavour in black pepper [15]. Among 90 black pepper and 40 white pepper samples analysed by proton transfer reaction-mass spectrometry, the black pepper samples had notably higher intensities for $41 \%$ (52 out of 128) of the masses compared with white pepper [16]. Most of the volatile organic compounds were found at higher concentrations in black pepper than in white pepper, except for five low-intensity compounds; butanoic acid $(\mathrm{m} / z \mathrm{89})$, its isotope $(\mathrm{m} / \mathrm{z} 90)$, ethyl propionate $(\mathrm{m} / z \mathrm{103})$ and methyl isovalerate $(\mathrm{m} / z$ 117) [16]. These results account for the relatively mild and delicate flavour of white pepper. White pepper is widely used in Europe because of its light colour [17, 18].

Although the chemical composition of black and white peppers has been investigated, so far, no study has determined the chemical components in the pericarp of pepper. When the pericarp is removed from pepper to make white pepper, it is normally discarded. If the pericarp can be used to manufacture other pepper products, it would be economically beneficial. In this study, we identified the chemical components and antioxidant activity of pepper pericarp, and the advantages of using this part of the pepper fruit for food.

\section{Materials and methods}

\section{Chemicals and materials}

Folin's phenol reagent, 1,1-diphenyl-2-picrylhydrazyl radical (DPPH), 2,2'-azino-bis(3-ethylbenzothiazoline6-sulfonic acid) (ABTS), 2,2'-azobis(2-amidinopropane) dihydrochloride (AAPB), D-catechin, gallic acid monohydrate and ethyl alcohol were prepared by MilliporeSigma (St. Louis, MO, USA). Nitric acid (Dongwoo Fine-Chem, Iksan, Korea) and standards of minerals (AccuStandard, New Haven, CT, USA), namely $\mathrm{Ca}, \mathrm{K}$, copper $(\mathrm{Cu})$, iron $(\mathrm{Fe}), \mathrm{Mg}$, manganese $(\mathrm{Mn})$, sodium $(\mathrm{Na})$ and zinc $(\mathrm{Zn})$, were used.

\section{Samples}

Pepper of $5 \mathrm{~kg}$ was prepared from mature peppercorns harvested in March 2017, by Ottogi Sesame Mills Co., Ltd (Eumseong, Choungcheonbuk-do, Korea). The peppercorns were separated from the stems after harvesting them, and then they were naturally sun-dried for 7-10 days to obtain a black colour. Finally, pericarp was mechanically peeled off from the pepper using a decorticating machine (Sinco Mechanical JSC, Vietnam). It was ground and sieved by 60 -mesh and then it was stored at room temperature in darkness.

\section{Sample preparation}

The ground pericarp sample of $5 \mathrm{~g}$ was homogenised with $80 \%$ ethyl alcohol of $100 \mathrm{~mL}$ using KWG-150 of Sunway Electric Manufacture (Heshan, China). The mixture was incubated for a day in shaking incubator (a DH.WIS 02011, Daihan Scientific Co., Ltd., Daegu, Gyeongbuk, Korea), followed by centrifugation at 15,000 rpm for $10 \mathrm{~min}$ (Mega21R, Hanil Scientific, Inc., Gimpo, Gyenggi-do, Korea). The upper layer was taken and filtered by a Minisart filter $(0.45 \mu \mathrm{m}$ pore size, regenerated cellulose) and then concentrated to $20 \mathrm{~mL}$ on a rotary evaporator (N-1000, Eyela, Tokyo, Japan). The extract was stored at $-80{ }^{\circ} \mathrm{C}$ until analyzing chemical components and antioxidant activities.

\section{Bioactive compounds and antioxidant activities of pepper pericarp Total flavonoids}

The total flavonoids were determined by a colorimetric assay $[19,20]$. A $1 \mathrm{~mL}$ of sample extract and distilled water $(4 \mathrm{~mL})$ were placed in a $15-\mathrm{mL}$ tube, then $0.3 \mathrm{~mL}$ of $5 \% \mathrm{NaNO}_{2}$ was added to the tube, and the mixture was left to react at room temperature for $5 \mathrm{~min}$. After adding $0.3 \mathrm{~mL}$ of $10 \% \mathrm{AlCl}_{3}$, the mixture was left to react further at room temperature for $6 \mathrm{~min}$ before $2 \mathrm{~mL}$ of $1 \mathrm{~N}$ $\mathrm{NaOH}$ was added. Distilled water was added to adjust the total volume to $10 \mathrm{~mL}$. The absorbance was recorded by a spectrophotometer (Optizen POP, Mecasys, Daejeon, Korea) at $510 \mathrm{~nm}$. Catechin was used as the standard to establish the calibration curve. Total flavonoids were expressed as milligrams of catechin equivalents (CE)/100 g fresh weight (FW).

\section{Total phenols}

The total phenols were analysed by the Folin-Ciocalteu colorimetric method [19, 20]. Folin-Ciocalteu reagent $(0.2 \mathrm{~mL})$ was added to a $15 \mathrm{~mL}$ tube containing $0.2 \mathrm{~mL}$ of the sample extract and $2.6 \mathrm{~mL}$ of distilled water. The mixture was left at room temperature for $6 \mathrm{~min}$, and then $0.2 \mathrm{~mL}$ of $7 \% \mathrm{Na}_{2} \mathrm{CO}_{3}$ was added, followed by incubation at room temperature for $90 \mathrm{~min}$ in the dark. Spectrophotometric absorbance was determined at $750 \mathrm{~nm}$. The total phenol contents were shown as milligrams of gallic acid equivalents (GAE)/100 g FW by evaluating a gallic acid calibration curve.

\section{Piperine}

Piperine was determined, as described by Santosh et al. with some modifications [21]. A $50 \mathrm{~mL}$ conical tube containing $0.1 \mathrm{~g}$ of the sample extract and $50 \mathrm{~mL}$ methanol was extracted by ultrasonication at $50^{\circ} \mathrm{C}$ for $20 \mathrm{~min}$. The extracted sample was cooled down at room temperature and filtered through a Minisart syringe filter $(0.45 \mu \mathrm{m}$, regenerated cellulose). Piperine was detected using a high-performance liquid chromatography (HPLC) apparatus (Agilent, Santa Clara, CA, USA) equipped with a diode array detector $(340 \mathrm{~nm})$ and Eclipse C18 Plus 
column $(4.6 \times 150 \mathrm{~mm}, 5 \mu \mathrm{m}$; Agilent $)$ maintained at $25{ }^{\circ} \mathrm{C}$. Acetonitrile-1\% citric acid $(45: 55, \mathrm{v} / \mathrm{v})$ was used as the mobile phase in isocratic mode at the flow rate of $1 \mathrm{~mL} / \mathrm{min}$ for $20 \mathrm{~min}$. The injection volume was $10 \mu \mathrm{L}$. Peak of piperine and its spectra in the HPLC chromatogram was identified (Fig. 1).

\section{DPPH radical scavenging activity}

DPPH radical scavenging activity was analyzed by the method reported by Brand-Williams et al. with some modifications [22]. DPPH solution $(100 \mu \mathrm{M})$ was diluted with $80 \%$ methanol to have an absorbance of $0.65 \pm 0.02$ at a wavelength of $517 \mathrm{~nm}$. The extracted sample $(50 \mu \mathrm{L})$ was mixed with $2950 \mu \mathrm{L}$ of DPPH diluted from $0.1 \mathrm{mM}$ of DPPH solution and reacted for $30 \mathrm{~min}$. The absorbance at $517 \mathrm{~nm}$ (Optizen POP spectrophotometer, Mecasys) was shown as milligrams of vitamin $C$ equivalents (VCE)/100 g FW.

\section{ABTS radical scavenging activity}

The ABTS radical scavenging activity was measured with an analytical method described by Floegel et al. [23]. ABTS (137.175 mg) and AAPH $(27.117 \mathrm{mg})$ were prepared in $100 \mathrm{~mL}$ of phosphate-buffer, followed by reaction in a water bath at $70{ }^{\circ} \mathrm{C}$ for $40 \mathrm{~min}$ to produce ABTS radicals, and then cooled down at room temperature. The working solutions were diluted with the ABTS radical solution by phosphate-buffered saline to obtain an optical density at $734 \mathrm{~nm}$ of between 0.63 and 0.67 . Finally, the sample $(20 \mu \mathrm{L})$ and working solution $(980 \mu \mathrm{L})$ were mixed and reacted at $37^{\circ} \mathrm{C}$ for $10 \mathrm{~min}$. The absorbance of the solution at $734 \mathrm{~nm}$ was determined by spectrophotometer (Optizen POP, Mecasys). The antioxidant activity of the solution was expressed as milligrams of $\mathrm{VCE} / 100 \mathrm{~g}$ FW.

\section{Flavour compounds by gas chromatography/mass spectrometry (GC/MS)}

Two grams of sample was added into an amber vial of $20 \mathrm{~mL}$ with PTFE/silicone septa, and it was equilibrated at $80{ }^{\circ} \mathrm{C}$ for $30 \mathrm{~min}$ with the headspace sampler under agitation at $300 \mathrm{rpm}$. GC/MS analysis was performed using a $6890 \mathrm{GC} / \mathrm{MS}$ system (Agilent Co., Santa Clara, CA, USA) installed with an HP-INNOWax column $(60 \mathrm{~m} \times 0.25 \mathrm{~mm} \times 0.25 \mu \mathrm{m}$; Agilent Co. $)$ [24]. The sample $(1 \mathrm{~mL})$ was injected by a syringe in split injection mode $(20: 1)$ at $230{ }^{\circ} \mathrm{C}$, with helium $(>99.9 \%$ purity) as the carrier gas at a flow rate of $1 \mathrm{~mL} / \mathrm{min}$. The oven was initially maintained at $40^{\circ} \mathrm{C}$ for $2 \mathrm{~min}$, then heated at a rate of $5^{\circ} \mathrm{C} / \mathrm{min}$ to $230^{\circ} \mathrm{C}$ and maintained at this temperature for $10 \mathrm{~min}$. The flavours were identified by comparison of the obtained spectra to library (NIST 2005, John Wiley \& Sons, New York, NY, USA). Figure 2 is the GC/MS chromatogram of the peaks of flavours in the black pepper pericarp.

\section{Flavour compounds by electronic nose (e-nose)}

A GC-type e-nose (Heracles II, Alpha MOS, Toulouse, France) with dual column (non-polar MXT-5 and slightly polar MXT-1701, $10 \mu$ length $\times 180 \mu \mathrm{m}$ diameter; Restek, Lisses, France) and dual flame ionisation detector (FID) was used for flavour component profile analysis. The oven temperature was increased from $50{ }^{\circ} \mathrm{C}$ (maintained for $2 \mathrm{~s})$ to $260^{\circ} \mathrm{C}$ at $1{ }^{\circ} \mathrm{C} / \mathrm{s}$. The sample $(0.8 \mathrm{~g})$ was transferred to a $20-\mathrm{mL}$ headspace vial and incubated at $50^{\circ} \mathrm{C}$ for $5 \mathrm{~min}$, with agitation at $500 \mathrm{rpm}$. Then, $1000 \mu \mathrm{L}$ was injected at a flow rate of $1 \mathrm{~mL} / \mathrm{min}$ and measured five times. For peak identification and principal component analysis (PCA), AroChemBase (NIST retention index database) and AlphaSoft (version 17.0; Alpha MOS) were used.

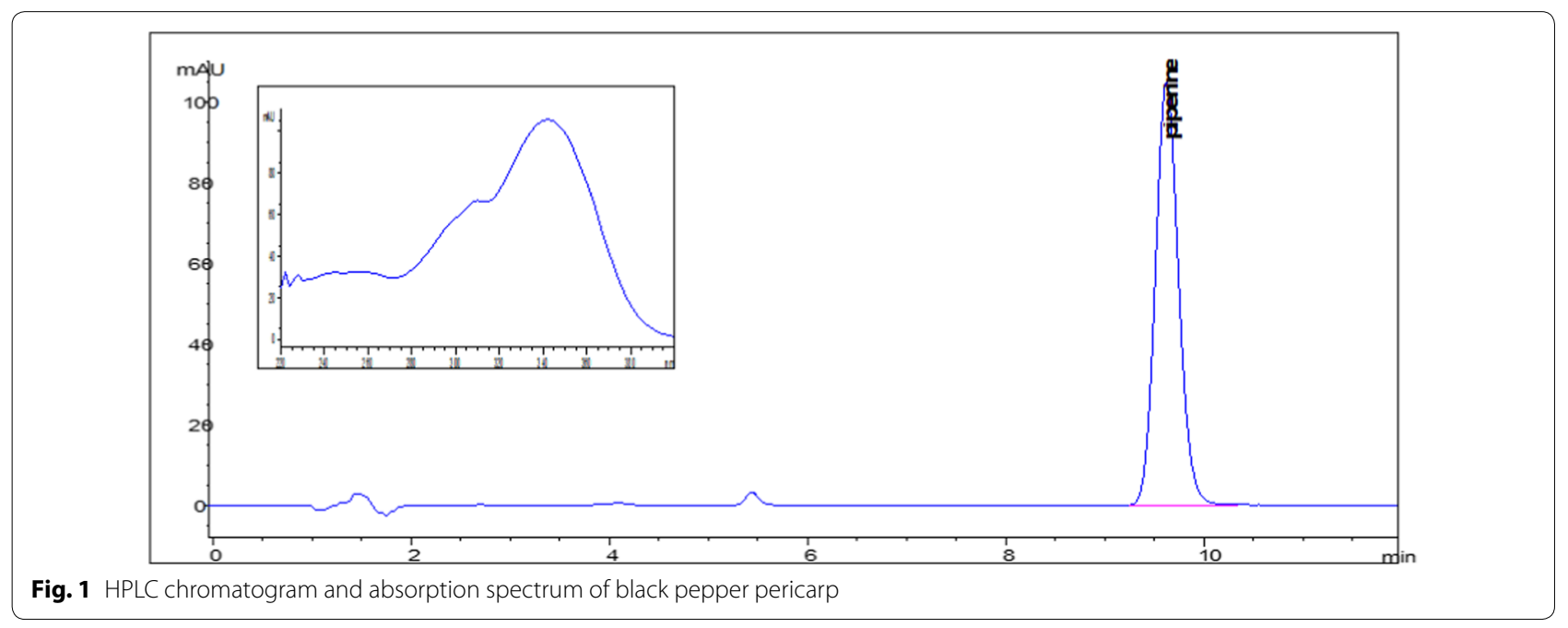


Abundanoe

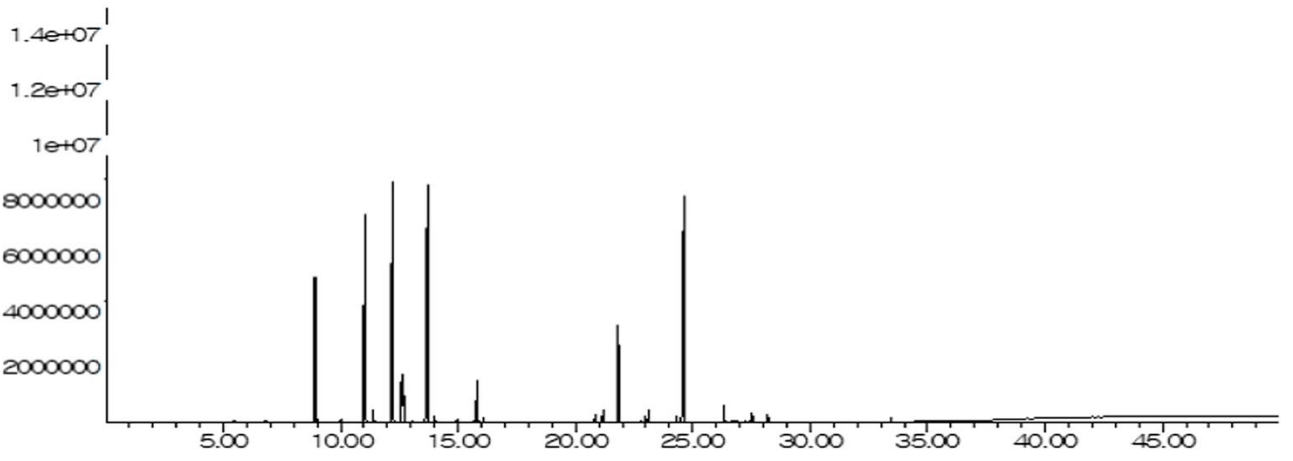

Fig. 2 GC/MS chromatogram of volatile compounds in black pepper pericarp

\section{Minerals}

$\mathrm{Ca}, \mathrm{Cu}, \mathrm{Fe}, \mathrm{K}, \mathrm{Mg}, \mathrm{Mn}, \mathrm{Na}$ and $\mathrm{Zn}$ were identified by the procedure developed by Jung et al. [24]. Aliquot of the sample of $0.6 \mathrm{~g}$ was prepared in a Teflon digestion vessel with concentrated nitric acid of $7 \mathrm{~mL}$, and it was digested for 40 min under incrementally increasing pressure heating at $1000 \mathrm{~W}$. The digested sample was diluted with water in flasks of $50 \mathrm{~mL}$ for analysis of the minerals using an inductively coupled plasma atomic emission spectrometer (ACTIVA-M, HORIBA Jobin-Yvon, Longjumeau, France) with a charge-coupled device. Argon gas plasma was used (flow rate of $13 \mathrm{~L} / \mathrm{min}$, sheath flow of $1.5 \mathrm{~L} / \mathrm{min})$. The absorption wavelengths were $317.933,324.754,238.207,766.490$, 285.213, 275.610, 589.592 and $213.857 \mathrm{~nm}$ for $\mathrm{Ca}$, $\mathrm{Cu}, \mathrm{Fe}, \mathrm{K}, \mathrm{Mg}, \mathrm{Mn}, \mathrm{Na}$ and $\mathrm{Zn}$, respectively. A multielement standard solution was diluted for calibration. The determined concentrations were shown as milligrams/100 g FW.

\section{Statistical analysis}

All experiments were conducted triplicately. Data were presented as mean \pm standard deviation using Microsoft Office Excel 2010 (Microsoft Corporation, Redmond, WA, USA). Analysis of variance was performed using SAS version 9.4 (SAS Institute, Inc., Cary, NC, USA) for the statistical analysis of each experiment. Significance was determined by Duncan's multiple range test with $\mathrm{p}<0.05$.

\section{Results and discussion}

Bioactive compounds and antioxidant activity of pepper pericarp

The total phenols, total flavonoids and piperine are important antioxidants in plants, including black pepper [11, 25, 26]. Pericarp contained total phenol, total flavonoid and piperine contents of $1421.95 \pm 22.35 \mathrm{mg}$ $\mathrm{GAE} / 100 \mathrm{~g}, \quad 983.82 \pm 8.19 \mathrm{mg} \mathrm{CE} / 100 \mathrm{~g}$ and $2352.19 \pm 68.88 \mathrm{mg} / 100 \mathrm{~g}$, respectively (Table 1). These data were compared with the corresponding

Table 1 Concentrations of total phenol, total flavonoid and piperine in black pepper pericarp

\begin{tabular}{|c|c|c|c|c|}
\hline Type & $\begin{array}{l}\text { Total phenol (mg } \\
\text { GAE/100 g) }\end{array}$ & Total flavonoid (mg CE/100 g) & Piperine (mg/100 g) & References \\
\hline Black pepper pericarp & $1421.95 \pm 22.35$ & $983.82 \pm 8.19$ & $2352.19 \pm 68.88$ & This study \\
\hline Methanol extract of black pepper & 172.8 & $108.7(\mu \mathrm{g} Q E / 100 \mathrm{~g})$ & & {$[37]$} \\
\hline White pepper, dried & $447.23 \pm 10.38$ & & & [38] \\
\hline Black pepper & 654 & 2149 ( $\mu \mathrm{g}$ QE/100 g) & & [39] \\
\hline Black pepper & $338 \pm 1.414$ & & & [40] \\
\hline Black pepper & $11.9 \pm 0.1$ & $2.1 \pm 0.2(\mu \mathrm{g} Q \mathrm{Q} / 100 \mathrm{~g})$ & & [41] \\
\hline Black pepper & & & 3950-7990 & [42] \\
\hline Black pepper & & & $5700-7800$ & [43] \\
\hline Black pepper & & & 3566.1 & [44] \\
\hline
\end{tabular}

GAE gallic acid equivalents, $C E$ catechin equivalents, $Q E$ quercetin equivalents 
literature values for black and white pepper and black pepper extract. Total phenols were from 11.9 to $654 \mathrm{mg}$ GAE/100 g in black pepper and $447.23 \mathrm{mg}$ GAE/100 g in white pepper. Total flavonoids were from 0.002 to 0.109 milligrams of quercetin equivalents ( $\mathrm{mg} \mathrm{QE}) / 100 \mathrm{~g}$ in black pepper and methanol extracts of black pepper (Table 1). The concentration of total phenols was higher in pericarp than black pepper, white pepper and the methanol extract of black pepper, whereas pericarp contained less piperine compared with black pepper. However, the concentrations of total flavonoids in black pepper and the black pepper extract were determined as quercetin equivalents, so a direct comparison with pericarp was not feasible.

The DPPH and ABTS antioxidant activities were $392.46 \pm 6.84$ and $1366.82 \pm 25.14 \mathrm{mg} \mathrm{VCE} / 100 \mathrm{~g} \mathrm{FW}$ for pericarp, and $225.33 \pm 6.84$ and $793.97 \pm 39.83 \mathrm{mg}$ VCE/100 g FW for black pepper, respectively. The DPPH and ABTS radical scavenging activities of pericarp were higher than those in black pepper by $42.5 .2 \%$ and $41.9 \%$, respectively.

\section{Flavor compounds by GC/MS}

Thirty-eight volatile flavour compounds were characterised in pericarp, and their peak areas were determined (Table 2). The main components were monoterpenes, sesquiterpenes and their oxygenated forms [27]. Most of the monoterpenes, except for linalool and 3-carene, were more volatile than the sesquiterpenes, with earlier retention times. The principal monoterpene compounds were $\alpha$-pinene $(9.2 \%), 2-\beta$-pinene $(14.3 \%), \delta$-3-carene $(21.5 \%)$ and DL-limonene $(18.8 \%)$, and the primary sesquiterpenes were $\alpha$-copaene $(5.1 \%)$ and caryophyllene (17.2\%). $\beta$-Pinene, $\delta$-3-carene, limonene and caryophyllene are abundant volatile flavour compounds in black, white and green peppers [28]. Pericarp contained a higher percentage of $\alpha$-pinene and $\alpha$-copaene than peppers. $\alpha$-Pinene imparts a terpenic odour, according to Murthy and Bhattacharya [29]. Therefore, the pericarp has a more terpenic odour than black, white and green peppers. $\beta$-Myrcene and linalool are known as the most potent odorants of black pepper, although they are relatively minor flavour compounds in black pepper $[15,17]$, as confirmed in the current work. Therefore, pericarp would have a more potent odour compared with black pepper.

\section{Flavor compounds by an electronic nose}

Black pepper, pericarp and inner kernel after removing the skin were analysed by an e-nose. Some of the discriminative volatile compounds were identified by the AroChemBase database (Table 3). Figure 3 shows the GC/FID of discriminative volatile compounds of black pepper, pericarp and inner kernel. 1R- $(+)-\alpha$-pinene,
Table 2 Volatile flavour compounds composition in the black pepper pericarp

\begin{tabular}{|c|c|c|c|c|}
\hline & Flavour compound & $\begin{array}{l}\text { Retention } \\
\text { time (min) }\end{array}$ & $\begin{array}{l}\text { Peak area }\left(\times 10^{6}\right), \\
\text { (\%area) }\end{array}$ & Type \\
\hline 1 & a-Pinene & 8.9 & $231.65 \pm 56.69,(9.2)$ & $\mathrm{m}$ \\
\hline 2 & a-Fenchene & 9.0 & $5.00 \pm 1.55,(0.2)$ & $\mathrm{m}$ \\
\hline 3 & Camphene & 10.0 & $5.17 \pm 1.68,(0.2)$ & $\mathrm{m}$ \\
\hline 4 & 2- $\beta$-Pinene & 11.0 & $333.21 \pm 81.81,(14.3)$ & $\mathrm{m}$ \\
\hline 5 & Sabinene & 11.4 & $14.45 \pm 4.81,(0.6)$ & $\mathrm{m}$ \\
\hline 6 & a-Terpinene & 11.6 & $0.70 \pm 0.21,(0.0)$ & $\mathrm{m}$ \\
\hline 7 & 8-3-Carene & 12.2 & $499.25 \pm 19.74,(21.5)$ & $\mathrm{m}$ \\
\hline 8 & $\beta$-Myrcene & 12.6 & $57.78 \pm 19.44,(2.5)$ & $\mathrm{m}$ \\
\hline 9 & 1-Phellandrene & 12.7 & $40.88 \pm 11.36,(1.8)$ & $\mathrm{m}$ \\
\hline 10 & Sabinene & 12.8 & $1.02 \pm 0.35,(0.0)$ & $\mathrm{m}$ \\
\hline 11 & a-Terpinene & 13.1 & $2.97 \pm 1.04,(0.1)$ & $\mathrm{m}$ \\
\hline 12 & DL-Limonene & 13.7 & $437.14 \pm 99.26,(18.8)$ & $\mathrm{m}$ \\
\hline 13 & $\beta$-Phellandrene & 14.0 & $7.94 \pm 2.35,(0.3)$ & $\mathrm{m}$ \\
\hline 14 & 1,8-cineole & 14.1 & $2.04 \pm 0.51,(0.1)$ & o.m \\
\hline 15 & a-Thujene & 14.9 & $1.35 \pm 0.39,(0.1)$ & $\mathrm{m}$ \\
\hline 16 & $\gamma$-Terpinene & 15.0 & $3.40 \pm 0.97,(0.1)$ & $\mathrm{m}$ \\
\hline 17 & o-Cymene & 15.7 & $3.44 \pm 1.11,(0.1)$ & $\mathrm{m}$ \\
\hline 18 & p-Cymene & 15.8 & $50.36 \pm 15.23,(2.2)$ & $\mathrm{m}$ \\
\hline 19 & a-Terpinolene & 15.9 & $2.57 \pm 0.85,(0.1)$ & $\mathrm{m}$ \\
\hline 20 & a-Terpinolene & 16.1 & $5.32 \pm 1.72,(0.2)$ & $\mathrm{m}$ \\
\hline 21 & a-Cubebene & 20.8 & $10.19 \pm 3.06,(0.4)$ & s \\
\hline 22 & $\delta$-Elemene & 21.2 & $16.02 \pm 4.83,(0.7)$ & s \\
\hline 23 & a-Amorphene & 21.6 & $1.64 \pm 0.37,(0.1)$ & s \\
\hline 24 & a-Copaene & 21.8 & $120.72 \pm 30.75$ & s \\
\hline 25 & a-Gurjunene & 22.8 & $2.78 \pm 0.68,(0.1)$ & s \\
\hline 26 & $\beta$-Cubebene & 23.0 & $7.45 \pm 1.99,(0.3)$ & s \\
\hline 27 & Linalool & 23.1 & $13.36 \pm 4.19,(0.6)$ & o.m \\
\hline 28 & germacrene A & 24.3 & $7.87 \pm 2.68,(0.3)$ & s \\
\hline 29 & Caryophyllene & 24.6 & $399.78 \pm 89.37,(17.2)$ & s \\
\hline 30 & a-Humulene & 26.3 & $19.30 \pm 5.11,(0.8)$ & s \\
\hline 31 & Linalyl propionate & 26.9 & $2.12 \pm 0.66,(0.1)$ & s \\
\hline 32 & germacrene D & 27.2 & $1.53 \pm 0.47,(0.1)$ & s \\
\hline 33 & $\beta$-bisabolene & 27.4 & $2.06 \pm 0.90,(0.1)$ & s \\
\hline 34 & $\beta$-selinene & 27.5 & $11.58 \pm 4.57,(0.5)$ & s \\
\hline 35 & a-selinene & 27.6 & $6.85 \pm 1.95,(0.3)$ & s \\
\hline 36 & §-Cadinene & 28.2 & $8.97 \pm 2.70,(0.4)$ & s \\
\hline 37 & 3-Carene & 28.5 & $1.09 \pm 0.38,(0.0)$ & $\mathrm{m}$ \\
\hline \multirow[t]{2}{*}{38} & Caryophyllene oxide & 33.5 & $5.18 \pm 1.51,(0.2)$ & 0.5 \\
\hline & Sum & & $2326.11 \pm 575.42,(100)$ & \\
\hline
\end{tabular}

$m$ monoterpene, o.m oxygenated monoterpene, $s$ sesquiterpene, o.s oxygenated sesquiterpene

$o$-chlorotoluene, cyclopentane, psi-cumene, heptyl mercaptan, dipentene, terpene, limonene, 3-methyldecane, 1-octanethiol, heptyl benzene and methyl undecanoate were identified as the main volatile compounds by an e-nose with two different columns. Although 
Table 3 Main volatile compounds identified by electronic nose in black pepper pericarp

\begin{tabular}{|c|c|c|c|c|c|c|c|}
\hline & \multirow[t]{2}{*}{ Flavor compounds } & \multicolumn{2}{|c|}{ Retention time (s) } & \multicolumn{2}{|c|}{ Peak area $\left(\times 10^{3}\right),(\% a r e a)$} & \multirow[t]{2}{*}{ Sensory description } & \multirow{2}{*}{$\begin{array}{l}\text { Peak area } \\
\text { comparision }\end{array}$} \\
\hline & & MXT-5 & MTX-1701 & MXT-5 & MTX -1701 & & \\
\hline 1 & 1R-(+)-a-pinene & 68.68 & 64.74 & $21.6(4.6)$ & $20.1(4.8)$ & Aromatic, harsh, minty, pine, terpenic & $B>P>1$ \\
\hline 2 & o-chlorotoluene & 76.33 & 74.05 & $67.6(14.4)$ & $52.0(12.3)$ & Aromatic & $B>P>1$ \\
\hline 3 & Cyclopentane, pentyl & - & 76.05 & & $11.7(2.8)$ & - & $B>P>1$ \\
\hline 4 & Psi-cumene & 81.65 & 78.89 & $104.1(22.1)$ & $94.7(22.5)$ & Aromatic herbaceous plastic & $B>P>1$ \\
\hline 5 & Heptyl mercaptan & 84.55 & 82.91 & $106.1(22.5)$ & $81.8(19.4)$ & Onion sulphurous & $B>P>1$ \\
\hline 6 & Dipentene/terpene/limonene & - & 85.82 & & $12.2(2.9)$ & Citrus green pine & $B>P>1$ \\
\hline 7 & 3-methyldecane & 94.30 & 92.96 & $4.9(1.0)$ & $1.1(0.3)$ & Balsamic mild phenolic & $B>P>1$ \\
\hline 8 & 1-octanethiol & 99.89 & 102.01 & $1.5(0.3)$ & $1.2(0.3)$ & Mild sulphurous & $B>P>1$ \\
\hline 9 & Heptyl benzene & 137.47 & 137.15 & $34.5(7.3)$ & $28.7(6.8)$ & - & $P>1>B$ \\
\hline 10 & Methyl undecanoate & 146.25 & 146.82 & $130.7(27.7)$ & $117.7(27.9)$ & Bland fatty fruity oily sweet waxy winey & $P>1>B$ \\
\hline
\end{tabular}

B: black pepper; P: pericarp of black pepper; I: inner kernel of black pepper after removing the pericarp

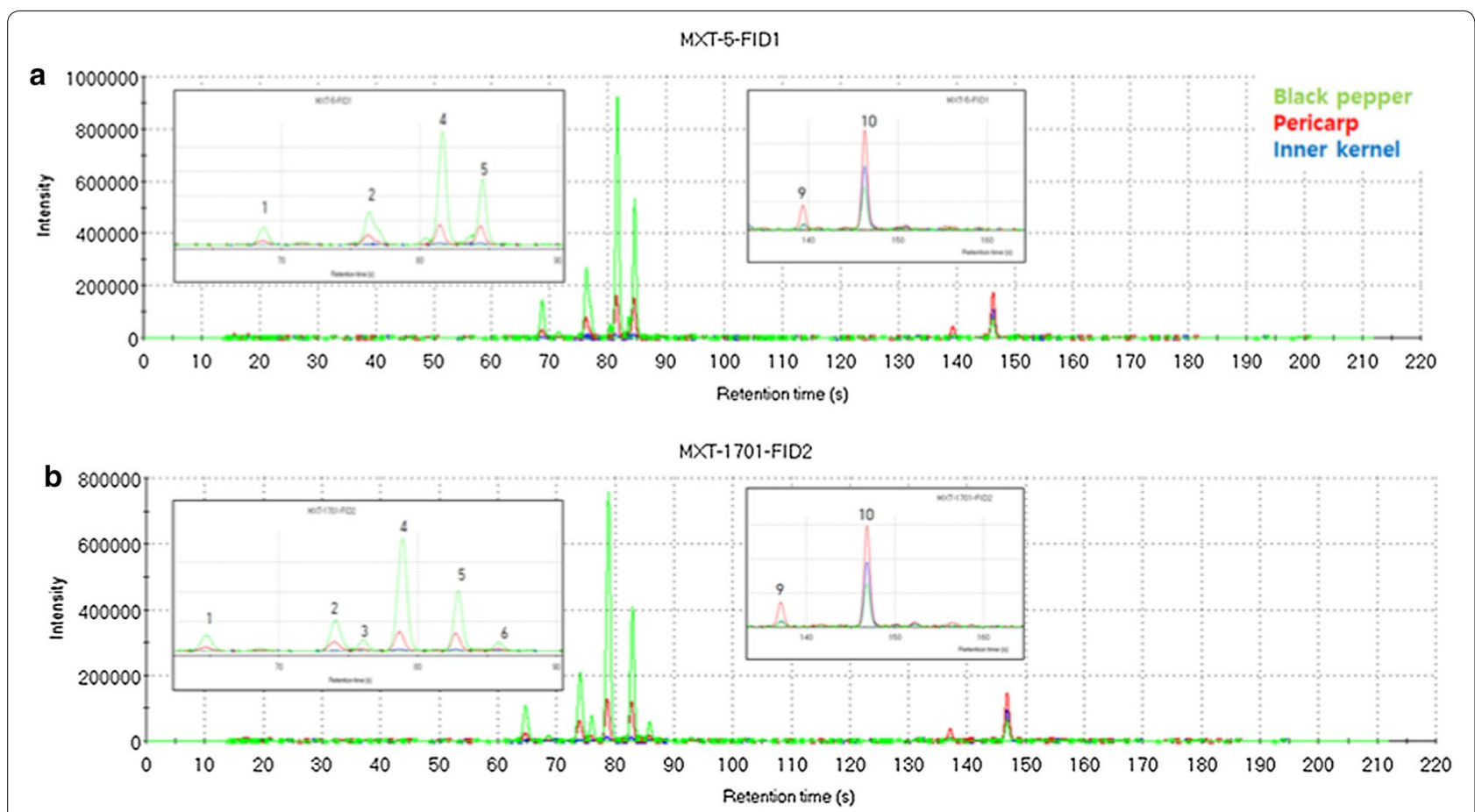

Fig. 3 GC/FID chromatogram of discriminant volatile compounds of black pepper, its pericarp and its inner kernel using an electronic nose with a MXT-5 column and $\mathbf{b}$ MXT-1701 column

some volatile compounds, such as pinene, terpene and limonene, were identified by GC/MS, most of the volatile compounds identified by an e-nose were not identified by GC/MS. Therefore, GC/MS is not suitable as the sole method to identify volatile flavour compounds in black pepper, and an e-nose should be simultaneously used. Furthermore, cyclopentane, pentyl and dipentene/ terpene/limonene were identified by only column MTX1701. Column MTX-1791 is better for e-nose analysis than column MTX-5. Pericarp contained higher peak areas of heptyl benzene and methyl undecanoate compared with black pepper.

Figure 4 shows an odour map based on PCA of all volatile compounds of black pepper, and the three-dimensional odour map based on PCA of the discriminative volatile compounds of black pepper, pericarp and inner kernel. PC1 and PC2 accounted for major differences $(99.379 \%)$ and minor differences $(0.5935 \%)$, respectively. 


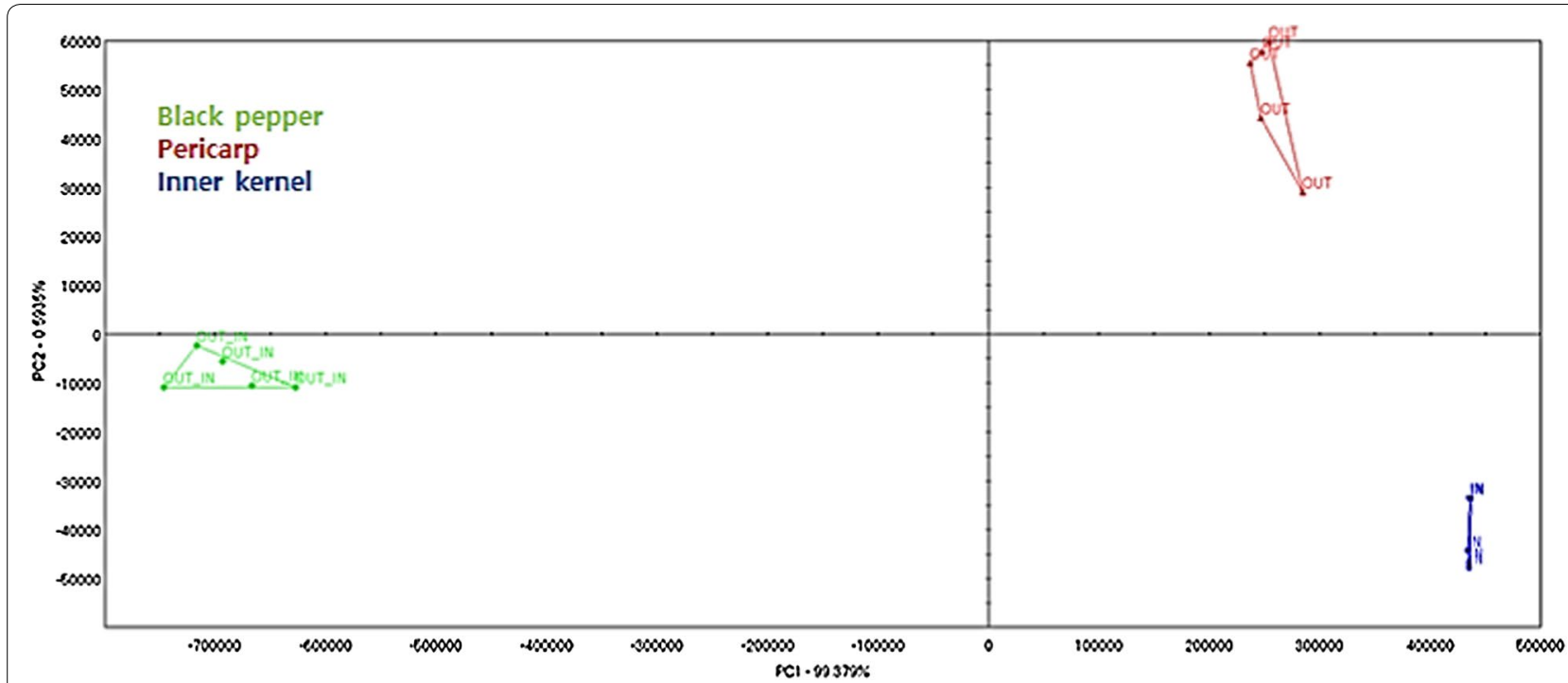

Fig. 4 An odour map of black pepper, its pericarp and its inner kernel based on principal component analysis

Table 4 Mineral contents in black pepper pericarp

\begin{tabular}{lccc}
\hline Mineral & \multicolumn{3}{l}{ Concentration $\mathbf{( m g / 1 0 0 ~} \mathbf{~})$} \\
\cline { 2 - 4 } & This study & $\begin{array}{l}\text { Al-Jasass } \\
\text { and Al-Jasser } \\
{[\mathbf{1 3}]}\end{array}$ & Özcan and Akbulut [30] \\
\hline $\mathrm{Mn}$ & $24.52 \pm 2.80$ & $3.5 \pm 0.2$ & $12.97 \pm 2.28$ \\
$\mathrm{Zn}$ & $1.02 \pm 0.01$ & $0.9 \pm 0.1$ & $0.93 \pm 0.09$ \\
$\mathrm{Mg}$ & $209.97 \pm 0.61$ & $52.0 \pm 8.0$ & $148.69 \pm 21.58$ \\
$\mathrm{Cu}$ & $0.90 \pm 0.02$ & $1.3 \pm 0.1$ & $0.48 \pm 0.06$ \\
$\mathrm{Ca}$ & $549.73 \pm 4.61$ & $195.0 \pm 15.0$ & $264.00 \pm 30.24$ \\
$\mathrm{Fe}$ & $42.44 \pm 1.08$ & $20.5 \pm 0.5$ & $8.92 \pm 1.14$ \\
$\mathrm{~K}$ & $2377.03 \pm 13.68$ & $663 \pm 25.0$ & $1000.60 \pm 49.75$ \\
$\mathrm{Na}$ & $7.44 \pm 0.11$ & - & $189.21 \pm 27.95$ \\
\hline
\end{tabular}

The flavour compounds in the various parts of black pepper had different flavour profiles, with the pericarp exhibiting higher minor and tiny differences. It shows that pericarp has a fruitful flavour than the other parts, as determined by GC/MS analysis.

\section{Minerals}

Based on the mineral composition of pericarp, $\mathrm{K}$ was the most abundant, followed by $\mathrm{Ca}, \mathrm{Mg}, \mathrm{Fe}, \mathrm{Mn}$ and $\mathrm{Na}$ (Table 4). Comparatively lower concentrations of $\mathrm{K}$, $\mathrm{Ca}, \mathrm{Mg}, \mathrm{Fe}, \mathrm{Mn}, \mathrm{Zn}$ and $\mathrm{Cu}$ have been reported in black pepper (Table 4) [13, 30]. Ca and $\mathrm{Mg}$ are important minerals in forming bone, strengthening heart functions, relaxing muscle, conducting memory and metaboliting glucose [31-33]. Black pepper pericarp would have stronger health effects than black pepper because of its higher concentrations of minerals. Moreover, it contained a much higher level of $\mathrm{K}$ relative to white bean $(463.1 \mathrm{mg} / 100 \mathrm{~g})$, one of the best sources of K. Black pepper contained higher concentrations of $\mathrm{Ca}$ compared with yoghurt $(181.6 \mathrm{mg} / 100 \mathrm{~g})$ and milk $(120 \mathrm{mg} / 100 \mathrm{~g})$, which are known to contain high levels of $\mathrm{Ca}$. The $\mathrm{Mg}$ level in black pepper pericarp was more than that mentioned in spinach $(87 \mathrm{mg} / 100 \mathrm{~g})$, tuna $(64 \mathrm{mg} / 100 \mathrm{~g})$ and brown rice $(44 \mathrm{mg} / 100 \mathrm{~g})$, and only slightly lower than that in almonds $(270 \mathrm{mg} / 100 \mathrm{~g})$ [34-36].

\section{Abbreviations}

DPPH: 2,2-Diphenyl-1-picrylhydrazyl; ABTS: 2,2'-Azino-bis (3-ethylbenzothiazoline-6-sulfonic acid).

\section{Acknowledgements}

This research was supported by the Basic Science Research Program through the National Research Foundation of Korea (NRF) funded by the Ministry of Education (NRF-2017R1D1A1B03036312).

\section{Authors' contributions}

JGL analyzed data and wrote the manuscript and YS analyzed the antioxidant ability. YC analyzed the flavours with e-nose analyzer. YJK organized this study and manuscript. All authors read and approved the final manuscript.

\section{Funding}

This research was supported by the Basic Science Research Program through the National Research Foundation of Korea (NRF) funded by the Ministry of Education (NRF-2017R1D1A1B03036312).

Availability of data and materials

All data analysed during this study are included in this published article.

\section{Competing interests}

The authors declare that they have no competing interests.

\section{Author details}

${ }^{1}$ Food Standard Division, Ministry of Food and Drug Safety, Heungduk, Cheongju 28159, South Korea. ${ }^{2}$ Centumtech, Gangseo, Seoul 07566, South Korea. ${ }^{3}$ Department of Food Engineering, Dankook University, Cheonan, 
Chungnam 31116, South Korea. ${ }^{4}$ Department of Food Science and Technology, Seoul National University of Science \& Technology, Nowon, Seoul, 01811, South Korea.

Received: 3 May 2020 Accepted: 30 June 2020

Published online: 09 July 2020

\section{References}

1. Purseglove JW, Brown EG, Green CL, Robbins SRT (1981) Spices: tropical agriculture series UK. Longman, London

2. Omafuvbe BO, Kolawole DO (2004) Quality assurance of stored pepper (Pipper guineense) using controlled processing methods. Pak J Nutr. 3:244-249

3. Agbor GA, Vinson JA, Oben JE, Ngogang JY (2006) Comparative analysis of the in vitro antioxidant activity of white and black pepper. Nutr Res. 26:659-663

4. Jeleń HH, Gracka A (2015) Analysis of black pepper volatiles by solid phase microextraction-gas chromatrography: a comparison of terpenes profiles with hydrodistillation. J Chromatogr A 1418:200-209

5. Ahmad N, Fazal H, Abbasi BH, Farooq S, Ali M, Khan MA (2012) Biological role of Piper nigrum L. (Black pepper): a review. Asian Pac J Trop Biomed. 2:S1945-S1953

6. Gülçín I (2005) The antioxidant and radical scavenging activities of black pepper (Piper nigrum) seeds. Int J Food Sci Nutr 56(7):491-499

7. Zaveri M, Khandhar A, Patel S, Patel A (2010) Chemistry and pharmacology of Piper longum L. Int J Pharm Sci Rev Res. 5(1):67-76

8. Gasparetto A, Cruz AB, Wagner TM, Bonomoni TJ, Correa R, Malheiros A (2017) Seasonal variation in the chemical composition, antimicrobial and mutagenic potential of essential oils from Piper cernum. Ind Crops Prod 95:256-263

9. Sauter IP, Rossa GE, Lucas AM, Cibulski SP, Roehe PM, da Silva LAA, Rott MB, Vargas RMF, Cassel E, von Poser GL (2012) Chemical composition and amoebicidal acitivity of Piper hispidinervum (Piperaceae) essential oil. Ind Crops Prod 40:292-295

10. Gorgani L, Mohammadi M, Najafpour GD, Nikzad M (2017) Piperinethe bioactive compound of black pepper: from isolation to medicinal formulations. Compr Rev Food Sci F. 16(1):124-140

11. Chonpathompikunlert P, Wattanathorn J, Muchimapura S (2010) Piperine, the main alkaloid of Thai black pepper, protects against neurodegeneration and cognitive impairment in animal model of cognitive deficit like condition of Alzheimer's disease. Food Chem Toxicol 48:798-802

12. Pradeep KU, Geervani P, Eggum BO (1993) Common indian spices: nutrient composition, consumption and contribution to dietary value. Plant Food Hum Nutr. 44:137-148

13. Al-Jasass FM, Al-Jasser MS (2012) Chemical composition and fatty acid content of some spices and herbs under Saudi Arabia conditions. Sci World J. https://doi.org/10.1100/2012/859892

14. Clery RA, Hammond CJ, Wright AC (2014) Nitrogen-containing compounds in black pepper oil (Piper nigrum L.). J Essent Oil Res 18:1-3

15. Jagella T, Grosch W (1999) Flavour and off-flavour compounds of black and white pepper (Piper nigrum L.) II. Odour activity values of desirable and undesirable odorants of black pepper. Eur Food Res Technol 209(1):22-26

16. Van Ruth SM, Silvis CJ, Ramos ME, Luning PA, Jansen M, Elliott CT, Alewijn M (2019) A cool comparison of black and white pepper grades. LWT-Food Sci Technol. 106:122-127

17. Jagella T, Grosch W (1999) Flavour and off-flavour compounds of black and white pepper (Piper nigrum L.) III. Desirable and undesirable odorants of white pepper. Eur Food Res Technol 209(1):27-31

18. Jin $C Q$, Jia $Y X$, Dong HX, Zhou JW, Sun GF, Zhang $Y Y$, Zhao Q, Zheng BY (2013) Stir-fired white pepper can treat diarrhea in infants and children efficiently: a randomized controlled trial. Am J Chin Med 41(4):765-772

19. Meyers KJ, Watkins CB, Pritts MP, Liu RH (2003) Antioxidant and antiproliferative activities of strawberries. J Agr Food chem. 51:6887-6892

20. Shin Y (2012) Correlation between antioxidant concentrations and activities of Yuja (Citrus junos Sieb ex Tanaka) and other citrus fruits. Food Sci Biotechnol. 21:1477-1482
21. Santosh MK, Shaila D, Rajyalakshmi I, Rao IS (2005) RP-HPLC method for determination of piperine from Piper longum Linn and Piper nigrum Linn. E J Chem. 2(2):131-135

22. Brand-Williams W, Cuvelier ME, Berset C (1995) Use of a free radical method to evaluate antioxidant activity. LWT-Food Sci Technol. 28:25-30

23. Floegel A, Kim DO, Chung SJ, Koo SI, Chung OK (2011) Comparison of ABTS/DPPH assays to measure antioxidant capacity in popular antioxidant-rich US foods. J Food composit anal. 24:1043-1048

24. Jung E, Kim Y, Joo N (2013) Physicochemical properties and antimicrobial activity of Roselle (Hibiscus sabdariffa L.). J Sci Food Agr. 93(15):3769-3776

25. Madsen HL, Nielsen BR, Bertelsen G, Skibsted LH (1996) Screen of antioxidative activity of spices. A comparison between assays based on ESR spin trapping and electrochemical measurement of oxygen consumption. Food Chem 57:331-337

26. Sun L, Zhang J, Lu X, Zhang L, Zhang Y (2011) Evaluation to the antioxidant activity of total flavonoids extract from persimmon (Diospyros kaki L.) leaves. Food Chem Toxicol 49(10):2689-2696

27. Buckle KA, Rathnawathie M, Brophy JJ (1985) Compositional differences of black, green and white pepper (Piper nigrum L.) oil from three cultivars. J Food Tech. 20:599-613

28. Liu H, Zeng F, Wang Q, Ou S, Tan L, Gu F (2013) The effect of cryogenic grinding and hammar milling on the flavour quality of ground pepper (Piper nigrum L.). Food Chem 141:3402-3408

29. Murthy $C T$, Bhattacharya $S$ (2008) Cryogenic grinding of black pepper. J Food Eng 85:18-28

30. Özcan MM, Akbulut M (2007) Estimation of minerals, nitrate and nitrite contents of medicinal and aromatic plants used as spices, condiments and herbal tea. Food Chem 106:852-858

31. Brody T (1994) Nutritional biochemistry. Academic Press, San Diego

32. Slutsky I, Abumaria N, Wu LJ, Huang C, Zhang L, Li B, Zhao X, Govindarjan A, Zhao MG, Zhuo M, Tonegawa S, Liu G (2010) Enhancement of learning and memory by elevating brain magnesium. Neuron 65(2):165-177

33. Veronese N, Watutantrige-Fernando S, Luchini C, Solmi M, Sartore G, Sergi G, Manzato E, Barbagallo M, Maggi S, Stubbs B (2016) Effect of magnesium supplementation on glucose metabolism in people with or at risk diabetes: a systematic review and meta-analysis of doubleblind randomized controlled trials. Eur J Clin Nutr 70:1354-1359

34. Jones T. 14 healthy foods which are high in potassium. 2017. https:// www.healthline.com/nutrition/high-potassium-foods. Accessed 22 Dec 2017

35. Whitbread D. Top 10 foods highest in magnesium. 2018. https://www. myfooddata.com/articles/foods-high-in-magnesium.php. Accessed 8 Apr 2020

36. National Institute of Health. Calcium: Fact sheet for health professionals. 2019. https://ods.od.nih.gov/factsheets/Calcium-HealthProfessio nal/. Accessed 26 Mar 2020

37. Ahmad A, Husain A, Mujeeb M, Khan SA, Alhadrami HAA, Bhandari A (2015) Quantification of total phenol, flavonoid content and pharmacognostical evaluation including HPTLC fingerprinting for the standardization of Piper nigrum Linn fruits. Asian Pac J Trop Biomed. 5(2):101-107

38. Tangkanakul P, Auttaviboonkul P, Niyomwit B, Lowvitoon N, Charoenthamawat P, Trakoontivakorn G (2009) Antioxidant capacity, total phenolic content and nutritional composition of Asian food after thermal processing. Int Food Res J. 16:571-580

39. Gupta D (2013) Comparative analysis of spices for their phenolic content, flavonoid content and antioxidant capacity. Am Int J Res Form Appl Nat Sci. 4(1):38-42

40. Nagy M, Socaci SA, Tofana M, Pop C, Muresan C, Pop A, Salanta L, Rotar AM (2015) Determination of total phenolics, antioxidant capacity and antimicrobial activity of selected aromatic spices. Bull Univ Agric Sci Vet Med Cluj-Napoca Food Sci Technol. 72(1):82-85

41. Mallick M, Bose A, Mukhi S (2016) Comparative evaluation of the antioxidant activity of some commonly used spices. Int J Pharm Res. $9(1): 1-8$

42. Wood AB, Barrow ML, James DJ (1988) Peperine determination in pepper (Piper nigrum L.) and its oleoresins-a reversed-phase highperformance liquid chromatographic method. Flavour Frag J. 3:55-64 
43. Graham H (1965) Quantitative determination of piperine. II. Direct determination with phosphoric acid. J Food Sci 30(4):651-655

44. Rao VRS, Raju SS, Sarma VU, Sabine F, Babu KH, Babu KS, Rao JM (2011) Simultaneous determination of bioactive compounds in Piper nigrum L. and a species comparison study using HPLC-PDA. Nat Prod Res 25(13):1288-1294

\section{Publisher's Note}

Springer Nature remains neutral with regard to jurisdictional claims in published maps and institutional affiliations.
Submit your manuscript to a SpringerOpen ${ }^{\odot}$ journal and benefit from:

- Convenient online submission

- Rigorous peer review

- Open access: articles freely available online

- High visibility within the field

- Retaining the copyright to your article

Submit your next manuscript at $\boldsymbol{\nabla}$ springeropen.com 